\title{
GROWTH OF THE BLUE SWIMMER CRAB, PORTUNUS PELAGICUS (LINNAEUS, 1758) (DECAPODA, BRACHYURA) IN CAPTIVITY
}

\author{
BY \\ JOSE JOSILEEN ${ }^{1}$ ) and N. G. MENON \\ Central Marine Fisheries Research Institute, P.O. Box 1603, Ernakulam, Cochin, \\ Kerala 682 018, India
}

\begin{abstract}
The growth of hatchery produced Portunus pelagicus crabs was monitored under laboratory conditions by recording growth at each moult from the $1^{\text {st }}$ crab instar onwards. Male and female crabs attained sexual maturity by their $12^{\text {th }}$ and $14^{\text {th }}$ moult, respectively. The experiment lasted for 455 days when the last crab died. This paper describes the growth of male and female crabs in each moulting stage, with details of their carapace width and length, chelar length and height, abdominal width and length, and total weight. Moulting frequency, secondary sexual characteristics, and moult increments were also monitored. VBGF (Von Bertalanffy Growth Formula) fit was obtained using the methods of Gulland \& Holt (1959), Fabens (1965), and Munro (1982). The $\mathrm{L}_{\infty}$ values calculated by the different methods ranged between 204.1 and $219.8 \mathrm{~mm}$ in males, and between 188.6 and $211.8 \mathrm{~mm}$ in females.
\end{abstract}

\section{RÉSUMÉ}

La croissance des crabes Portunus pelagicus nés en écloserie a été suivie en conditions de laboratoire en notant la croissance à chaque mue à partir du $1^{\mathrm{er}}$ stade crabe. Les crabes mâles et femelles atteignaient la maturité sexuelle à leur $12^{\mathrm{ème}}$ et $14^{\mathrm{ème}}$ mue, respectivement. L'expérience s'est terminée après 455 jours à la mort du dernier crabe. Ce travail décrit la croissance des crabes mâles et femelles à chaque stade de mue, avec les détails de largeur et longueur de la carapace, longueur et hauteur des pinces, largeur et longueur de l'abdomen et poids total. La fréquence des mues, les caractères sexuels secondaires, et les augmentations de mue étaient également suivis. La VBGF (formule de croissance de Von Bertalanffy) a été calculée en utilisant les méthodes de Gulland \& Holt (1959), Fabens (1965) et Munro (1982). Les valeurs de $\mathrm{L}_{\infty}$ calculées par les différentes méthodes étaient de 204,1 à 219,8 mm chez les mâles et 188,6 à 211,8 mm chez les femelles.

\section{INTRODUCTION}

The blue swimmer crab, Portunus pelagicus (Linnaeus, 1758), is the major marine crab landed from bottom trawl nets and set gill nets in India. Because of

\footnotetext{
1) e-mail: joslinjoys@ rediffmail.com

(C) Koninklijke Brill NV, Leiden, 2005

Also available online: www.brill.nl
}

Crustaceana 78 (1): $1-18$ 
its importance in terms of availability, abundance, and local or export demand, a detailed investigation was conducted on its growth pattern. Moreover, in recent years shrimp culture has encountered heavy losses due to disease outbreaks in Asia, which warrants the need to diversify culture operations in order to utilize the farm and to include other biologically suitable and economically viable crustaceans in the production process. The authors have studied the complete larval development of the species in an elaborative way (Josileen \& Menon, 2004) and mass seed production technology has also been developed (Josileen, 2001). The present study provides information on the suitability of the blue swimmer crab for mariculture.

Crustaceans are equipped with a hard exoskeleton that must be shed in order to grow, i.e., through moulting or ecdysis. Quantifying patterns of crustacean growth is difficult. Although there have been many studies, there is no generally accepted or convincing model describing crustacean growth, which is comparable to the models widely applied to fish growth. Among the reasons for this are the complications of incremental, discontinuous growth by moulting and the variety of life history strategies expressed by crustaceans. The best way of describing the growth of many crustacean species is by observing their moulting pattern. Crustacean growth is dependent upon the duration of the intermoult (moult interval) and size increase at each moult (moult increment) (Hartnoll, 1982). The processes of the moulting cycle have been adequately described by Skinner (1985).

This paper presents the growth of $P$. pelagicus from the first crab stage to sexual maturity, and further to the $16^{\text {th }}$ crab stage. Moulting frequencies in males and females, growth increment (length, width, weight), secondary sexual characteristics, the maturation moult, and behaviour during moulting are all described.

\section{MATERIALS AND METHODS}

The growth of Portunus pelagicus from the first instar to stage 16 was studied by rearing the crabs in the laboratory. For this purpose, the juvenile blue swimmer crabs were produced in the hatchery. Forty-five healthy crabs (instar I) within a size range of 2.0-2.5 mm carapace width $(\mathrm{CW})$ were used for the experiments (a total of 3 trials, with 15 crabs each).

First instar crabs were stocked in two-litre capacity plastic tubs (one crab in each tub), reared until they attained $10 \mathrm{~mm} \mathrm{CW}$, and then transferred to 30-litre capacity plastic tubs (one crab in each tub) until they reached a minimum size of $35 \mathrm{~mm} \mathrm{CW}$. Plastic tubs were provided with a sand bottom and small shelters. These experiments were conducted at a salinity of $35 \pm 1 \%$ in filtered seawater. Ninety percent water exchange was done once each morning between 08.30 and 
09.30 hours. Animals were fed with egg-prawn custard until the size of $10 \mathrm{~mm} \mathrm{CW}$ and later with fresh clam meat and small shrimps. Every day before feeding, excess feed and faecal matter were siphoned out and the water was replaced. Continuous aeration was provided in each tub. The tubs were arranged in such a way that all of them received a uniform exposure to light. Animals were observed daily for moulting. After each moult and subsequent sufficient hardening, morphometric and weight measurements were taken. The exuviae were collected and preserved.

Crabs above the size of $35 \mathrm{~mm} \mathrm{CW}$ were transferred to a 1000-1 capacity fibreglass tank (at a maximum of 5 specimens /tank) provided with a sand bottom and coral stones, and with bamboo baskets as shelters. Each animal was given a number, using a "Letro" label maker. The label was attached to the carapace and readily visible through the water column, making it easy to identify and locate the moulted crab (fig. 1). Following each moult and after sufficient hardening of the exoskeleton, a new label was attached to the crab's carapace and measurements

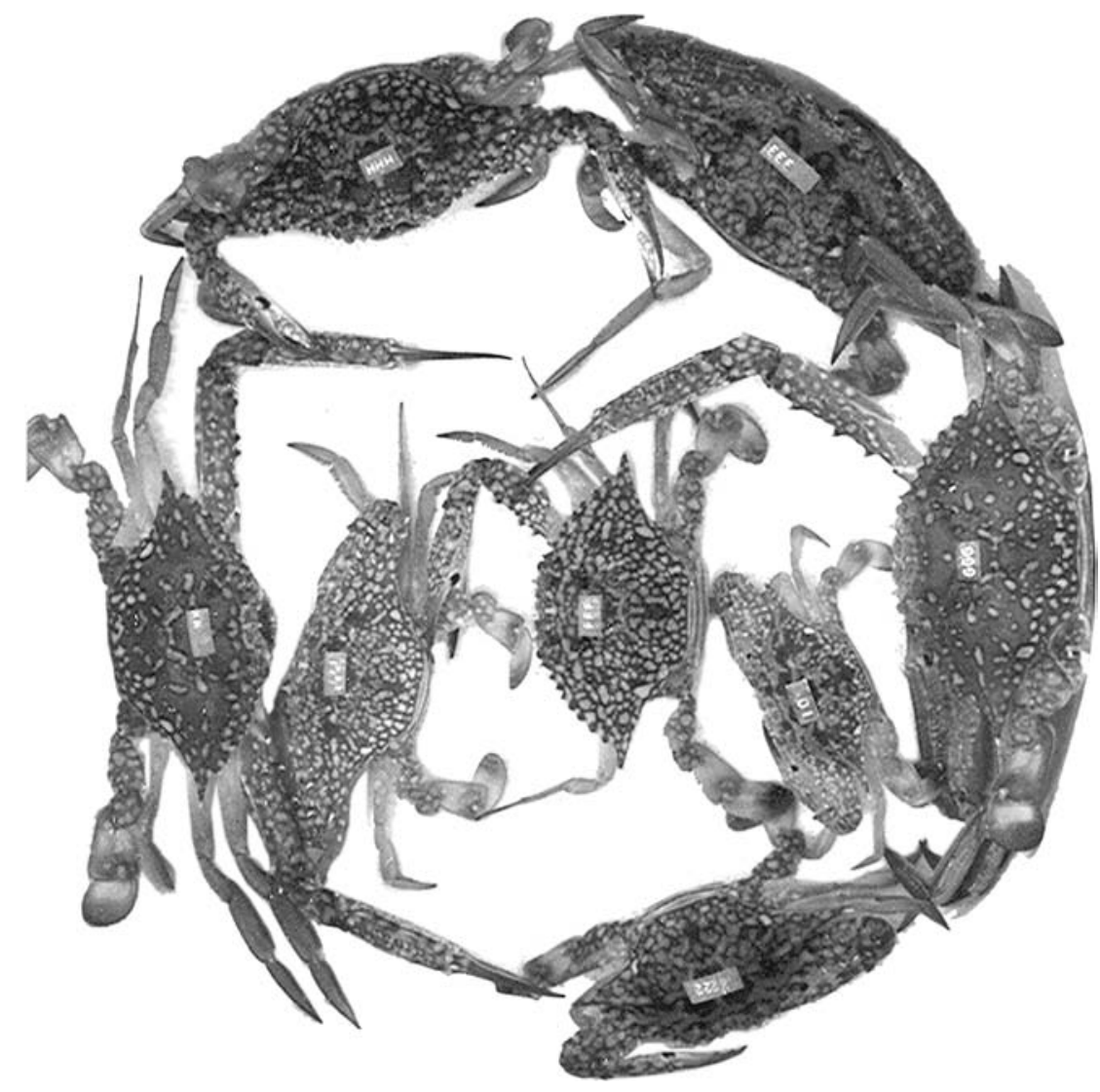

Fig. 1. A group of experimental specimens of Portunus pelagicus (Linnaeus, 1758) with 'identity stickers' on the carapace. 
were taken. Fifty percent of the water was exchanged daily. The feeding schedule as well as the observations continued as described above.

The maturation system for the crabs was developed in the hatchery following the methods suggested by Maheswarudu et al. (1996). The crabs above $60 \mathrm{~mm}$ CW were transferred into a collapsible polyvinyl pool of 8' diameter (approx. $2.50 \mathrm{~m}$ ) with an 8000-litre capacity. An in situ sand bed filter of 5-10 cm height was set on a perforated, false bottom that was installed at about $15 \mathrm{~cm}$ height over the entire surface area of the maturation pool. Four PVC tubes of $1 \mathrm{~m}$ height and $50 \mathrm{~mm}$ diameter were fixed vertically in the peripheral region of the sand bed at equal distances. The water column in the pool above the sand bed was maintained at $75 \mathrm{~cm}$ depth. An air-water lifting system was arranged in the tank through the air dispersing stones. Water recirculation was maintained at the rate of $300 \%$ per day by lifting the filtered seawater from below the sand bed through the PVC pipes. Daily, a 25-30\% water exchange was given and once in a week exchange was $100 \%$. The pool was covered with a lid to reduce light intensity $(<100$ lux $)$. Water $\mathrm{pH}$ was maintained at $8.0-8.2$ by the addition of sodium carbonate whenever necessary. Individual numbers were given to the crabs in the same way as mentioned above. The animals were fed daily ad libitum with clam meat, shrimp meat, and squid meat in the morning and evening hours. Faecal matter and untaken food were siphoned out in the morning before water exchange. Animals were observed regularly, especially the female crabs, i.e., for spawning frequency in each moult cycle.

Water quality plays an important role in growth and maturation in captivity and the following water quality parameters were maintained throughout the experiment: salinity, $35 \pm 1 \%$; temperature, $26-30^{\circ} \mathrm{C}$; $\mathrm{PH}, 8.2 \pm 0.1$; dissolved $\mathrm{O}_{2}$, 5-7 mg/l; ammonia, <0.1 ppm; nitrite, $<0.05 \mathrm{ppm}$.

Temperature was monitored using a thermometer graduated $0-50^{\circ} \mathrm{C}$. A digital meter was used for the determination of $\mathrm{pH}$. Salinity was determined with a refractometer (ACUTE, Japan). Nitrite and ammonia were estimated using a nutrient kit (Merck, Germany).

Data analysis. - The data of the laboratory rearing experiments on the growth of male and female crabs were entered as a growth increment data file in the computer program FiSAT. Further analysis of growth increment for fitting a growth curve was carried out using Gulland \& Holt (1959), Fabens (1965) and Munro's (1982) methods. The estimates of $\mathrm{L}_{\infty}$ and $\mathrm{K}$ thus obtained were analysed using the inverse Von Bertalanffy growth equation, to arrive at corresponding length at age. The optimum parameters ( $\mathrm{L}_{\infty}$ and $\mathrm{K}$ ) were fixed, based on the data obtained during the laboratory growth studies. 


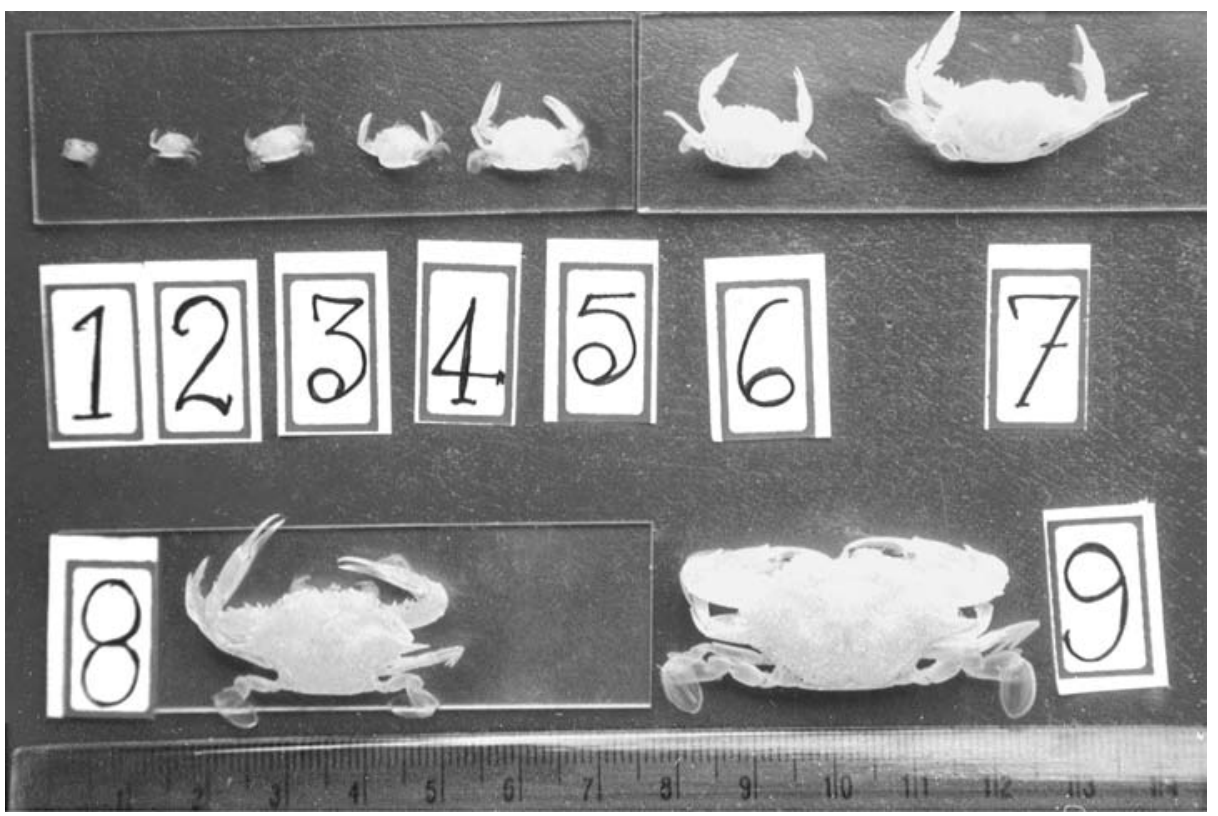

Fig. 2. Moulted shells of crab instars 1-9 of Portunus pelagicus (Linnaeus, 1758) grown in the laboratory.

\section{RESULTS}

Male crabs grew from an initial average carapace width of $2.38 \pm 0.18 \mathrm{~mm}$ to $159.86 \pm 3.52 \mathrm{~mm} \mathrm{CW}$, i.e., from first instar to $16^{\text {th }}$ instar in a mean period of 272 days. Males were reared to a maximum of 455 days. The average total weight gained was $275.00 \pm 25.41 \mathrm{~g}$ from an initial weight of $0.008 \mathrm{~g}$ (table I).

Female crabs grew from an initial average $\mathrm{CW}$ of $2.43 \pm 0.34 \mathrm{~mm} \mathrm{CW}$ to $154.31 \pm 2.73 \mathrm{~mm}$, and reached the $16^{\text {th }}$ instar in a mean of 332 days. The average weight gain during that period was from $0.006 \mathrm{~g}$ to $210.33 \pm 18.39 \mathrm{~g}$ (table II, and figs. 2, 3).

In male crabs, the average growth increment in carapace width increased steadily through the juvenile phase up to the $14^{\text {th }}$ moult and then decreased. The same pattern of growth was observed in carapace length until the $14^{\text {th }}$ moult. There after, it began to fluctuate. The highest percent growth per moult $(\mathrm{CW})$ occurred from the $1^{\text {st }}$ to $2^{\text {nd }}$ instar $(77.73 \%)$ and the lowest percentage was during the moult from $15^{\text {th }}$ to $16^{\text {th }}$ instar $(13.06 \%)$. The carapace length increment showed the highest percentage growth per moult from the $11^{\text {th }}$ to $12^{\text {th }}$ instar $(37.99 \%)$ while the lowest was from the $14^{\text {th }}$ to $15^{\text {th }}$ instar, $(11.12 \%)$ (table III).

In females, the growth increment in carapace width increased through the $12^{\text {th }}$ instar and then declined. The maximum percentual increase in carapace width was in the $1^{\text {st }}$ to $2^{\text {nd }}$ instar $(68.72 \%)$ and the lowest was from the $15^{\text {th }}$ to $16^{\text {th }}$ instar 


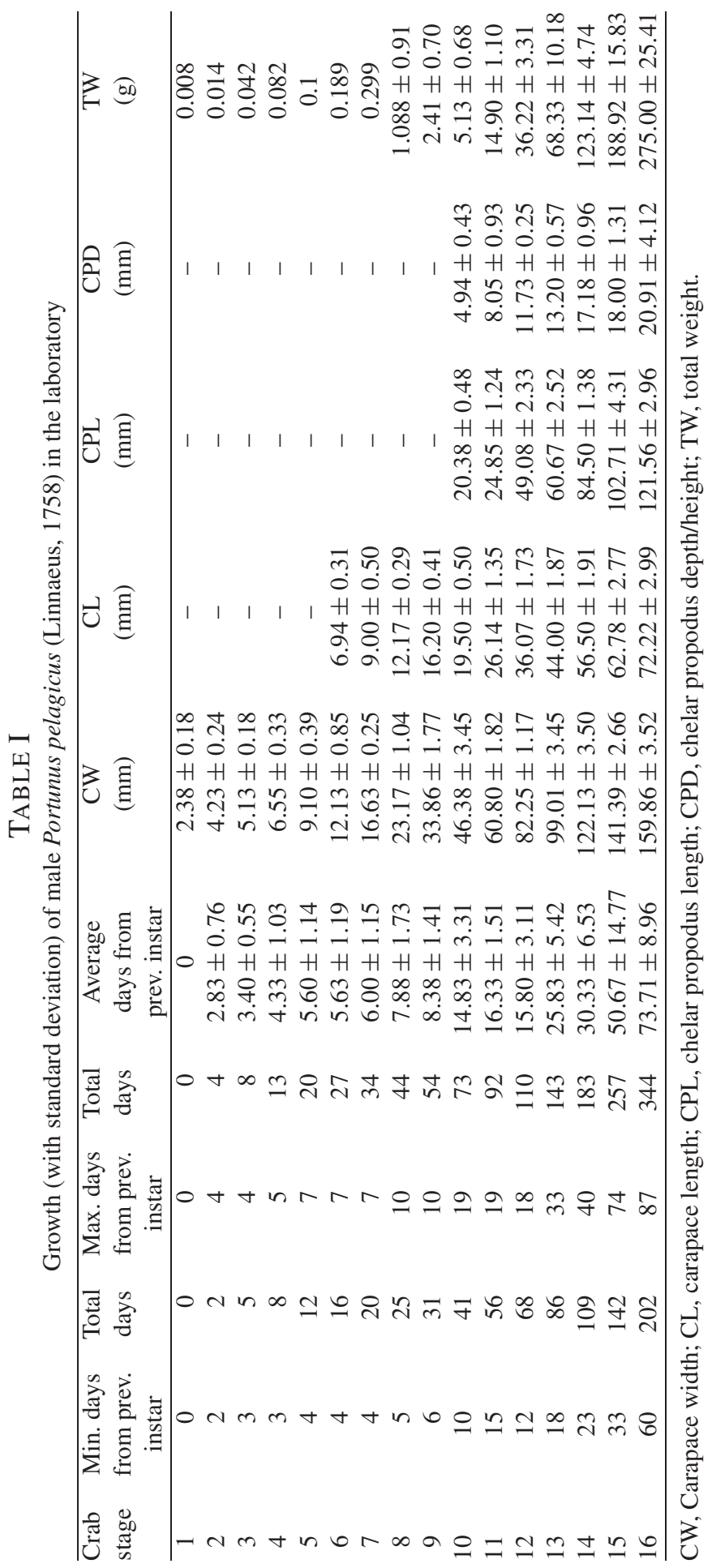


GROWTH OF PORTUNUS PELAGICUS (L.)

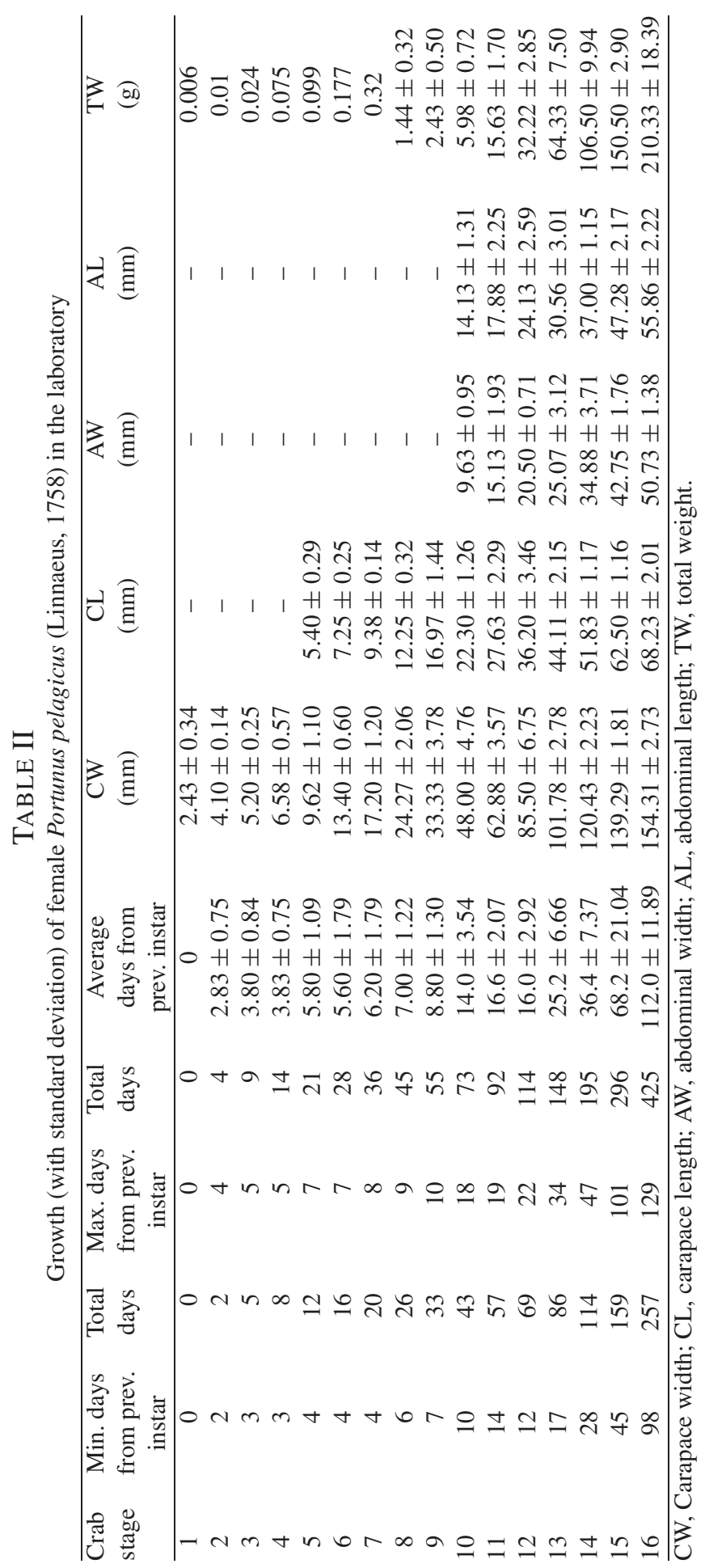




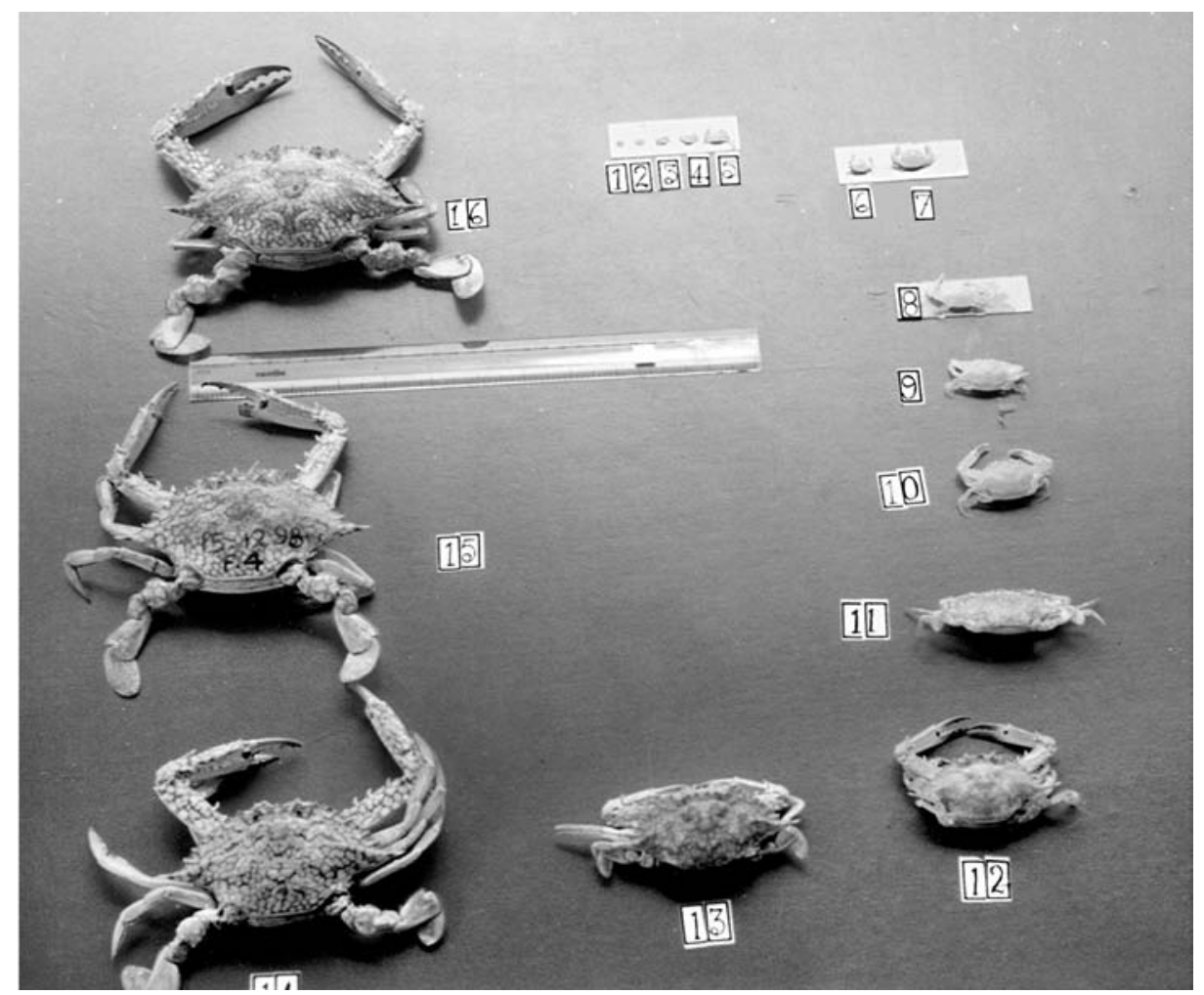

Fig. 3. Moulted shells of crab instars 1-16 of female Portunus pelagicus (Linnaeus, 1758) grown in the laboratory.

$(10.78 \%)$, as is the case in males. The moult increment pattern for carapace length was similar to that of carapace width. The maximum percent increase in carapace length was observed from the $8^{\text {th }}$ to $9^{\text {th }}$ instar $(38.53 \%)$ and the lowest percentage was from the $15^{\text {th }}$ to $16^{\text {th }}$ stage, $(9.17 \%)$ (table IV).

In crabs, there are certain morphological features that come to full expression at sexual maturity. These secondary sexual characters are prominent in both sexes. In males, pubertal changes include the colour of the chelae and other pereiopods, length and height of the pereiopods, and length of the first pleopods relative to the sternites in the sternal depression. In the present study, there was a drastic change in the length of the chelae in males by their $12^{\text {th }}$ moult. The total growth increment was $24.23 \mathrm{~mm}$ from the previous moult, accompanied by a $97.51 \%$ increase in chelar propodus length. Chelar propodus height also increased, i.e., by $3.68 \mathrm{~mm}$ $(45.71 \%)$, but this was more prominent in subsequent, mature moult.

The onset of sexual maturity was explicit in female crabs, too. In contrast to males, the passage of a female through the pubertal moult was indicated by gross changes in the abdomen and accessory reproductive structures. The most evident 


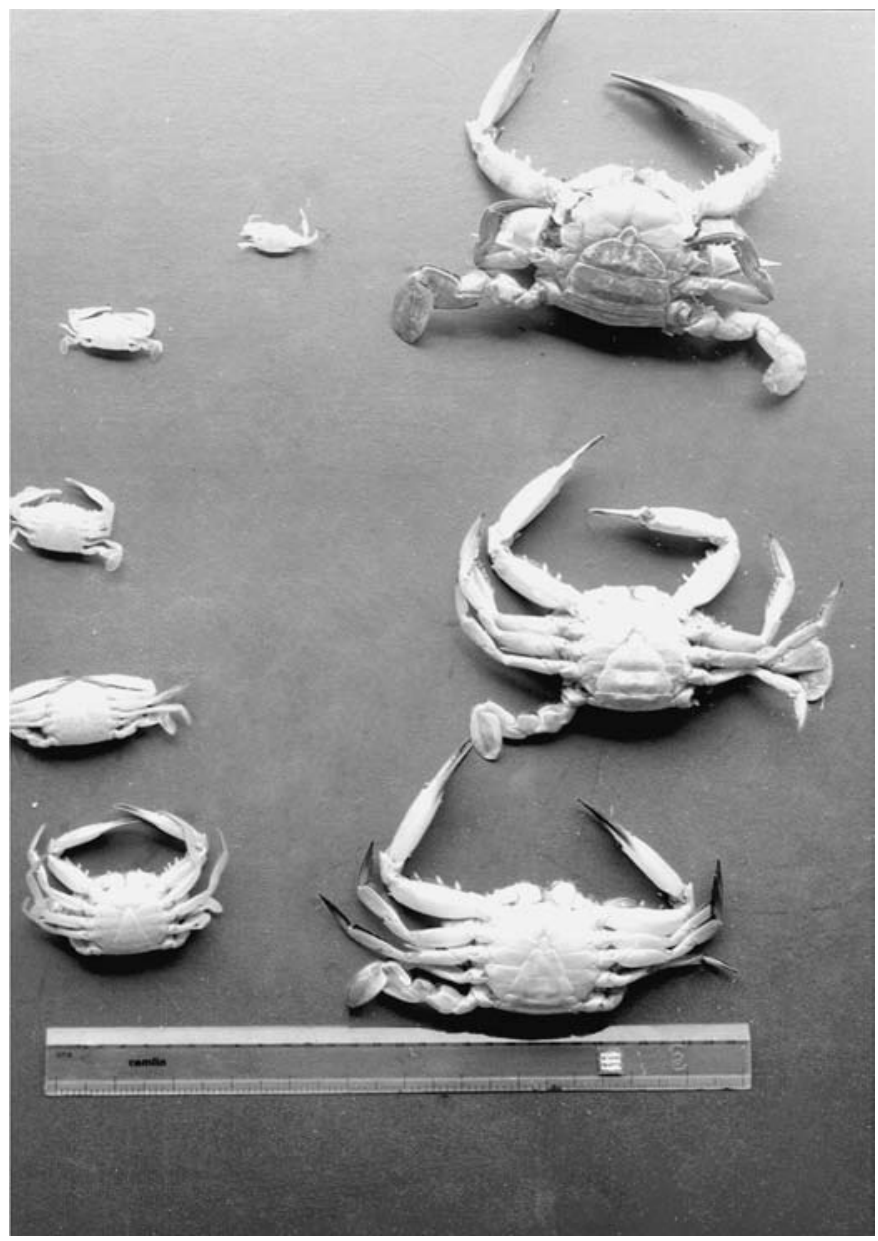

Fig. 4. Moulted shells of laboratory reared female Portunus pelagicus (Linnaeus, 1758), showing the increase in abdominal width during subsequent moultings.

in the female was the change of the triangular abdomen to an oval shape, which in the course of later moults almost became semicircular (fig. 4). In juveniles, the abdomen was held tightly against the sternum. By the pubertal moult, the abdominal flap became free and all abdominal somites articulated freely and were bordered by small setae. If the abdomen of the female was lifted, the round oviduct openings were seen. These openings were slit-like in juvenile crabs. There are four pairs of biramous pleopods on the second to fifth abdominal somites and the pleopodal endopodites bear clusters of long, silky setae to which the eggs are attached during spawning.

Another interesting observation in the female pubertal moult was the peculiar colouration on the dorsal surface of the abdomen. When a female approaches its 
TABLE III

Growth increments (average) in laboratory reared male Portunus pelagicus (Linnaeus, 1758)

\begin{tabular}{rcccccccccr}
\hline $\begin{array}{l}\text { Crab } \\
\text { stage }\end{array}$ & $\begin{array}{c}\mathrm{CW} \\
(\mathrm{mm})\end{array}$ & $\%$ & $\begin{array}{c}\mathrm{CL} \\
(\mathrm{mm})\end{array}$ & $\%$ & $\begin{array}{c}\mathrm{CPL} \\
(\mathrm{mm})\end{array}$ & $\%$ & $\begin{array}{c}\mathrm{CPD} \\
(\mathrm{mm})\end{array}$ & $\%$ & $\begin{array}{c}\text { TW } \\
(\mathrm{g})\end{array}$ & $\%$ \\
\hline 1 & - & - & - & - & - & - & - & - & - & - \\
2 & 1.85 & 77.73 & - & - & - & - & - & - & 0.006 & 75.00 \\
3 & 0.90 & 21.28 & - & - & - & - & - & - & 0.028 & 200.00 \\
4 & 1.42 & 27.68 & - & - & - & - & - & - & 0.040 & 95.24 \\
5 & 2.55 & 38.93 & - & - & - & - & - & - & 0.018 & 21.95 \\
6 & 3.03 & 33.30 & - & - & - & - & - & - & 0.089 & 89.00 \\
7 & 4.50 & 37.10 & 2.06 & 29.68 & - & - & - & - & 0.110 & 58.20 \\
8 & 6.54 & 39.33 & 3.17 & 35.22 & - & - & - & - & 0.789 & 263.88 \\
9 & 10.69 & 46.14 & 4.03 & 33.11 & - & - & - & - & 1.322 & 121.51 \\
10 & 12.52 & 36.98 & 3.30 & 20.37 & - & - & - & - & 2.720 & 112.86 \\
11 & 14.42 & 31.09 & 6.64 & 34.05 & 4.47 & 21.93 & 3.11 & 62.96 & 9.770 & 190.45 \\
12 & 21.45 & 35.28 & 9.93 & 37.99 & 24.23 & 97.51 & 3.68 & 45.71 & 21.320 & 143.09 \\
13 & 16.76 & 20.38 & 7.93 & 21.99 & 11.59 & 23.61 & 1.47 & 12.53 & 32.110 & 88.65 \\
14 & 23.12 & 23.35 & 12.5 & 28.41 & 23.83 & 39.28 & 3.98 & 30.15 & 54.810 & 80.21 \\
15 & 19.26 & 15.77 & 6.28 & 11.12 & 18.21 & 21.55 & 0.82 & 4.77 & 65.780 & 53.42 \\
16 & 18.47 & 13.06 & 9.44 & 15.04 & 18.85 & 18.35 & 2.91 & 16.17 & 86.080 & 45.56
\end{tabular}

$\mathrm{CW}$, Carapace width; CL, carapace length; CPL, chelar propodus length; CPD, chelar propodus depth/height; TW, total weight.

TABLE IV

Growth increments (average) in laboratory reared female Portunus pelagicus (Linnaeus, 1758)

\begin{tabular}{rcccccccccr}
\hline $\begin{array}{c}\text { Crab } \\
\text { stage }\end{array}$ & $\begin{array}{c}\mathrm{CW} \\
(\mathrm{mm})\end{array}$ & $\%$ & $\begin{array}{c}\mathrm{CL} \\
(\mathrm{mm})\end{array}$ & $\begin{array}{c}\text { AW } \\
(\mathrm{mm})\end{array}$ & $\begin{array}{c}\text { AL } \\
(\mathrm{mm})\end{array}$ & $\%$ & $\begin{array}{r}\text { TW } \\
(\mathrm{g})\end{array}$ & $\%$ \\
\hline 1 & - & - & - & - & - & - & - & - & - & - \\
2 & 1.67 & 68.72 & - & - & - & - & - & - & 0.004 & 66.67 \\
3 & 1.10 & 26.83 & - & - & - & - & - & - & 0.014 & 140.00 \\
4 & 1.38 & 26.54 & - & - & - & - & - & - & 0.051 & 212.50 \\
5 & 3.04 & 46.20 & - & - & - & - & - & - & 0.024 & 32.00 \\
6 & 3.78 & 39.29 & 1.85 & 34.26 & - & - & - & - & 0.078 & 78.79 \\
7 & 3.80 & 28.36 & 2.13 & 29.38 & - & - & - & - & 0.143 & 80.79 \\
8 & 7.07 & 41.10 & 2.87 & 30.60 & - & - & - & - & 1.120 & 350.00 \\
9 & 9.06 & 37.33 & 4.72 & 38.53 & - & - & - & - & 0.990 & 68.75 \\
10 & 14.67 & 44.01 & 5.33 & 31.41 & - & - & - & - & 3.550 & 146.09 \\
11 & 14.88 & 31.00 & 5.33 & 23.90 & 5.50 & 57.11 & 3.75 & 26.54 & 9.650 & 161.37 \\
12 & 22.62 & 35.97 & 8.57 & 31.02 & 5.37 & 35.49 & 6.25 & 34.96 & 16.590 & 106.14 \\
13 & 16.28 & 19.04 & 7.91 & 21.85 & 4.57 & 22.29 & 6.43 & 26.65 & 32.110 & 99.66 \\
14 & 18.65 & 18.32 & 7.72 & 17.50 & 9.81 & 39.13 & 6.44 & 21.07 & 42.170 & 65.55 \\
15 & 18.86 & 15.66 & 10.67 & 20.59 & 7.87 & 22.56 & 10.28 & 27.78 & 44.000 & 41.31 \\
16 & 15.02 & 10.78 & 5.73 & 9.17 & 7.98 & 18.67 & 8.58 & 18.15 & 59.830 & 39.75 \\
\hline
\end{tabular}

CW, Carapace width; CL, carapace length; AW, abdominal width; AL, abdominal length; TW, total weight. 


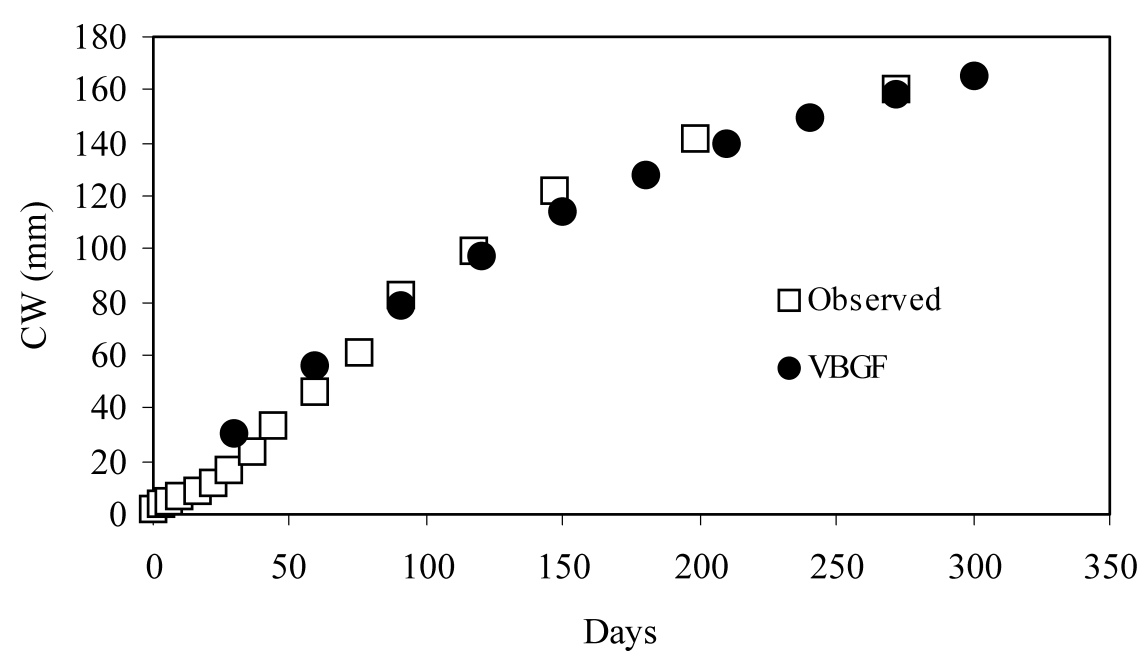

Fig. 5. Observed and fitted growth (Von Bertalanffy Growth Formula) in male Portunus pelagicus (Linnaeus, 1758) grown in the laboratory.

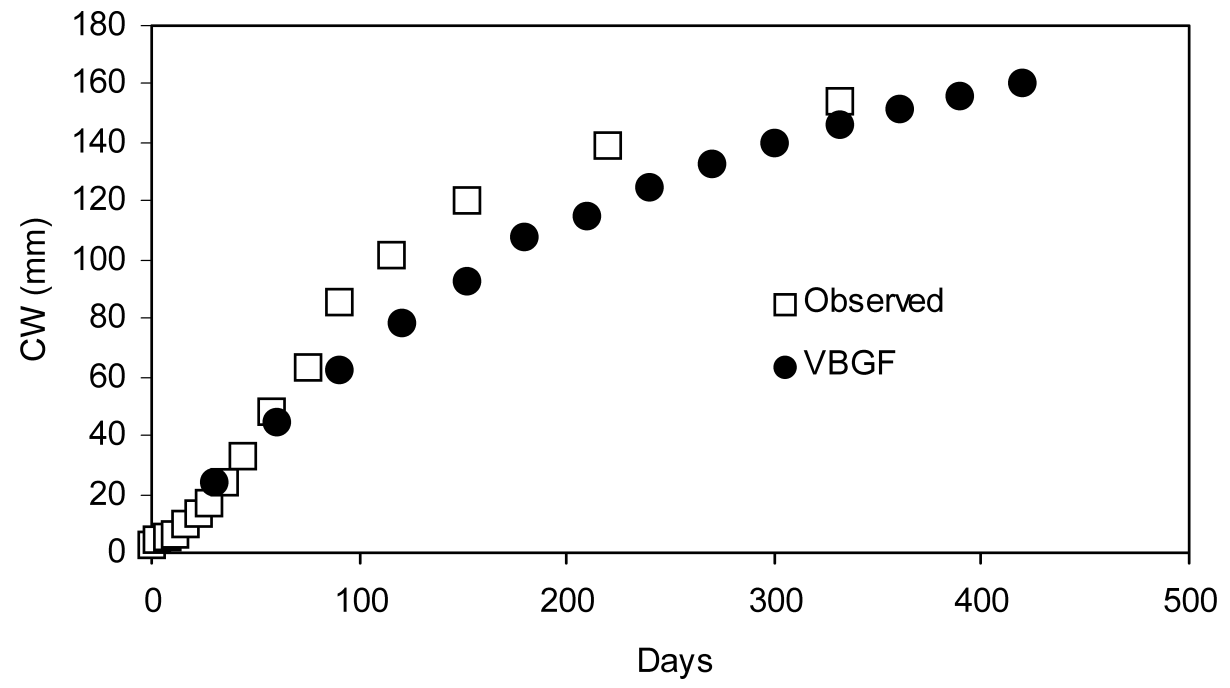

Fig. 6. Observed and fitted growth (Von Bertalanffy Growth Formula) in female Portunus pelagicus (Linnaeus, 1758) grown in the laboratory.

pubertal moult, or moults from one mature instar to the next, the dorsal surface of the abdomen attains a bluish-brown colour that persists for 3 to 4 days. This colour gradually disappears as the principal layer of the exoskeleton becomes fully calcified and the abdomen then changes to white, a colour similar to the other white under-surfaces. This bluish-brown colour was also associated with the prepubertal moult, but was not prominent as in the pubertal moult. It provided an 
TABLE V

Details of Von Bertalanffy Growth Formula and Growth Coefficient in male and female Portunus pelagicus (Linnaeus, 1758)

\begin{tabular}{lccl}
\hline Method & $\mathrm{L}_{\infty}(\mathrm{mm})$ & $\mathrm{K}$ & Growth equation \\
\hline Male & & & \\
Gulland \& Holt (1959) & 219.8 & 1.82 & $\mathrm{~L}_{(\mathrm{t})}=219.8\left\{1-\exp ^{-1.82\left(\mathrm{t}-\mathrm{t}_{0}\right)}\right\}$ \\
Munro (1982) & 208.0 & 1.90 & $\mathrm{~L}_{(\mathrm{t})}=208.0\left\{1-\exp ^{-1.90\left(\mathrm{t}-\mathrm{t}_{0}\right)}\right\}$ \\
Fabens (1965) & 204.1 & 1.80 & $\mathrm{~L}_{(\mathrm{t})}=204.1\left\{1-\exp ^{-1.80\left(\mathrm{t}-\mathrm{t}_{0}\right)}\right\}$ \\
Female & & & \\
Gulland \& Holt (1959) & 211.8 & 1.70 & $\mathrm{~L}_{(\mathrm{t})}=211.8\left\{1-\exp ^{-1.70\left(\mathrm{t}-\mathrm{t}_{0}\right)}\right\}$ \\
Munro (1982) & 21.0 & 1.64 & $\mathrm{~L}_{(\mathrm{t})}=211.0\left\{1-\exp ^{-1.64\left(\mathrm{t}-\mathrm{t}_{0}\right)}\right\}$ \\
Fabens (1965) & 188.6 & 1.62 & $\mathrm{~L}_{(\mathrm{t})}=188.0\left\{1-\exp ^{-1.62\left(\mathrm{t}-\mathrm{t}_{0}\right)}\right\}$ \\
\hline
\end{tabular}

indication that the next moult of the animal would be the maturation moult. In the present study, the abdominal width increment was $9.81 \mathrm{~mm}(39.13 \%)$ during the maturation moult. The maximum abdominal length increase was during the $15^{\text {th }}$ moult, i.e., $10.28 \mathrm{~mm}(27.78 \%)$.

In male crabs, the weight increment steadily increased after each moult. The maximum percentage of weight gain was from the $7^{\text {th }}$ to $8^{\text {th }}$ moult $(263.88 \%)$ and the minimum was from the $4^{\text {th }}$ to $5^{\text {th }}$ moult $(21.95 \%)$. In females, like in males, the maximum and minimum percentual incremental changes in weight were recorded during the $7^{\text {th }}$ to $8^{\text {th }}$ moult $(257.50 \%)$, and $4^{\text {th }}$ to $5^{\text {th }}$ moult $(32.00 \%)$, respectively. In general, the percentage of growth decreased after maturity, particularly in female crabs.

The growth in length of laboratory grown male and female Portunus pelagicus was analysed. Linear growth had a high correlation value, but the fitted growth curve was linear only during the juvenile phase. Growth followed the asymptotic curve as given in the Von Bertalanffy Growth Formula (VBGF) (figs. 5, 6), thus the data were analysed for VBGF using three different methods: Gulland \& Holt (1959), Fabens (1965) and Munro (1982). The $\mathrm{L}_{\infty}$ values ranged between 204.1 and $219.8 \mathrm{~mm}$ in males and 188.6 and $211.8 \mathrm{~mm}$ in females. The growth coefficient $(\mathrm{K})$ varied from 1.8 to 1.9 and 1.62 to 1.7 in males and females, respectively. The details are given in the table $\mathrm{V}$.

Based on the $\mathrm{L}_{\infty}$ and $\mathrm{K}$ values, monthly growth values of $P$. pelagicus male and female crabs were computed using the inverse VBGF, and are presented in the tables VI and VII. The monthly growth estimates of male $P$. pelagicus following Munro's method (1982), when compared to actually observed data, gave very close values, while in females the observed mean growth was close to that observed in the Fabens (1965) method. Accordingly, at the end of $1^{\text {st }}, 2^{\text {nd }}$, and $3^{\text {rd }}$ year, males 
attained a length of $176.9,203.3$ and $207.3 \mathrm{~mm}$ and females of 151.3, 181.2 and $187.2 \mathrm{~mm}$, respectively.

\section{DISCUSSION}

The results of the laboratory studies show that growth is fast, and a carapace width of $100 \mathrm{~mm}$ was reached in an average period of four months. This is a commercially accepted size, though at present there is no minimum size regulation for crab fishery in the country. Males attained maturity earlier than females: three months as opposed to five months for females. Only two reports are available on the laboratory growth of Portunus pelagicus from Indian waters: Prasad \& Tampi (1953) reported that megalopae of P. pelagicus collected from Palk Bay, Mandapam, took one month to attain a size of $8.5 \mathrm{~mm} \mathrm{CW}$. In the present study, the maximum number of days taken by megalopae to reach a crab size of approximately $9 \mathrm{~mm} \mathrm{CW}$ was 24 days and the minimum was 16 days. In the present study, the intermoult duration is shorter, however, a comparison with Prasad \& Tampi's (1953) data is difficult, as their conclusions were based on a single experiment. From the same geographical area, Ameer Hamsa (1982) reported that $11-25 \mathrm{~mm} \mathrm{CW} P$. pelagicus reared in tanks attained a size of $140-150 \mathrm{~mm}$ in 12 moults after a period of 14 months. In the present study, the $11-25 \mathrm{~mm}$ size group includes three instar groups $\left(6^{\text {th }}, 7^{\text {th }}\right.$, and $\left.8^{\text {th }}\right)$ and, it took only 6-7 months to grow to $140 \mathrm{~mm}\left(15^{\text {th }}\right.$ instar) (tables I, II). In the present study, growth was more rapid and crabs reached the same size in almost half the time. Hence, the range given by Ameer Hamsa (1982) might have included different instar groups.

Similarly, Menon (1952) gave the moulting and growth of the closely related portunid crab, Portunus sanguinolentus (Herbst, 1783) (as Neptunus sanguinolentus). He inferred that there were 11 moults in the course of growth from 13 to $60 \mathrm{~mm}$, based on one year of fishery data. These moult numbers are much higher than in P. pelagicus, which moulted only 5 times in this size range. Only by rearing the crabs in captivity, the number of moults can be confirmed.

The average moult increments in males and females up to a carapace width of $100 \mathrm{~mm}$ or, in other words, till the attainment of sexual maturity, were equal, and at larger sizes the moult increment of females was considerably less. Mackay \& Weymouth (1935), Butler (1961) and Bennett (1974) have come to similar conclusions. In females, the annual growth is less than that of males, due to their lesser moult increments and lower moulting frequency. Lesser moult increments may be due to the utilization of nutrients for egg production and body growth. Portunid crabs are capable of multiple spawnings from a single insemination at 
TABLE VI

Monthly growth of laboratory grown male Portunus pelagicus (Linnaeus, 1758) (based on the Von Bertalanffy Growth Formula)

\begin{tabular}{|c|c|c|c|c|}
\hline Age & $\begin{array}{c}\mathrm{L}_{\infty} \\
\mathrm{K}\end{array}$ & $\begin{array}{c}219.8 \\
1.82\end{array}$ & $\begin{array}{c}204.1 \\
1.80\end{array}$ & $\begin{array}{c}208.0 \\
1.9\end{array}$ \\
\hline Month & Year & & & \\
\hline 1 & 0 & 30.90 & 28.40 & 30.50 \\
\hline 2 & 0 & 57.50 & 52.90 & 56.50 \\
\hline 3 & 0 & 80.40 & 74.00 & 78.60 \\
\hline 4 & 0 & 100.00 & 92.10 & 97.60 \\
\hline 5 & 0 & 116.90 & 107.70 & 113.80 \\
\hline 6 & 0 & 131.30 & 121.10 & 127.60 \\
\hline 7 & 0 & 143.80 & 132.70 & 139.30 \\
\hline 8 & 0 & 154.50 & 142.60 & 149.40 \\
\hline 9 & 0 & 163.70 & 151.20 & 158.00 \\
\hline 10 & 0 & 171.60 & 158.60 & 165.30 \\
\hline 11 & 0 & 178.40 & 164.90 & 171.60 \\
\hline 12 & 1 & 184.20 & 170.40 & 176.90 \\
\hline 13 & 1 & 189.20 & 175.10 & 181.40 \\
\hline 14 & 1 & 193.50 & 179.10 & 185.30 \\
\hline 15 & 1 & 197.20 & 182.60 & 188.70 \\
\hline 16 & 1 & 200.40 & 185.60 & 191.50 \\
\hline 17 & 1 & 203.10 & 188.20 & 193.90 \\
\hline 18 & 1 & 205.50 & 190.40 & 196.00 \\
\hline 19 & 1 & 207.50 & 192.30 & 197.70 \\
\hline 20 & 1 & 209.20 & 194.00 & 199.20 \\
\hline 21 & 1 & 210.70 & 195.40 & 200.50 \\
\hline 22 & 1 & 212.00 & 196.60 & 201.60 \\
\hline 23 & 1 & 213.10 & 197.60 & 202.50 \\
\hline 24 & 2 & 214.10 & 198.50 & 203.30 \\
\hline 25 & 2 & 214.90 & 199.30 & 204.00 \\
\hline 26 & 2 & 215.60 & 200.00 & 204.60 \\
\hline 27 & 2 & 216.20 & 200.60 & 205.10 \\
\hline 28 & 2 & 216.70 & 201.10 & 205.50 \\
\hline 29 & 2 & 217.10 & 201.50 & 205.90 \\
\hline 30 & 2 & 217.50 & 201.90 & 206.20 \\
\hline 31 & 2 & 217.80 & 202.20 & 206.50 \\
\hline 32 & 2 & 218.10 & 202.40 & 206.70 \\
\hline 33 & 2 & 218.40 & 202.70 & 206.90 \\
\hline 34 & 2 & 218.60 & 202.90 & 207.00 \\
\hline 35 & 2 & 218.70 & 203.00 & 207.20 \\
\hline 36 & 3 & 218.90 & 203.20 & 207.30 \\
\hline
\end{tabular}

the previous moult. This could be a reason for the longer moulting cycle in female crabs. Williamson (1900) suggested that the presence of sperm in the spermathecae of a female crab inhibits moulting, and that a batch of sperm will fertilize two or more annual spawnings. The weight of male crabs is also considerably greater 
TABLE VII

Monthly growth of laboratory grown female Portunus pelagicus (Linnaeus, 1758) (based on the Von Bertalanffy Growth Formula)

\begin{tabular}{|c|c|c|c|c|}
\hline & $\mathrm{L}_{\infty}$ & $\begin{array}{c}196.9 \\
105\end{array}$ & $\begin{array}{c}190.4 \\
137\end{array}$ & $\begin{array}{r}190.0 \\
142\end{array}$ \\
\hline $\begin{array}{l}\text { Age } \\
\text { Month }\end{array}$ & $\begin{array}{c}\text { K } \\
\text { Year }\end{array}$ & 1.05 & 1.37 & \\
\hline 1 & 0 & 16.5 & 20.5 & 21.2 \\
\hline 2 & 0 & 31.6 & 38.9 & 40.0 \\
\hline 3 & 0 & 45.5 & 55.2 & 56.8 \\
\hline 4 & 0 & 58.1 & 69.8 & 71.7 \\
\hline 5 & 0 & 69.8 & 82.8 & 84.9 \\
\hline 6 & 0 & 80.4 & 94.4 & 96.6 \\
\hline 7 & 0 & 90.2 & 104.8 & 107.0 \\
\hline 8 & 0 & 99.1 & 114.0 & 116.3 \\
\hline 9 & 0 & 107.3 & 122.2 & 124.5 \\
\hline 10 & 0 & 114.8 & 129.6 & 131.8 \\
\hline 11 & 0 & 121.7 & 136.1 & 138.3 \\
\hline 12 & 1 & 128.0 & 142.0 & 144.1 \\
\hline 13 & 1 & 133.8 & 147.2 & 149.2 \\
\hline 14 & 1 & 139.0 & 151.9 & 153.8 \\
\hline 15 & 1 & 143.9 & 156.0 & 157.8 \\
\hline 16 & 1 & 148.3 & 159.7 & 161.4 \\
\hline 17 & 1 & 152.4 & 163.0 & 164.6 \\
\hline 18 & 1 & 156.1 & 166.0 & 167.4 \\
\hline 19 & 1 & 159.5 & 168.6 & 170.0 \\
\hline 20 & 1 & 162.7 & 170.9 & 172.2 \\
\hline 21 & 1 & 165.5 & 173.0 & 174.2 \\
\hline 22 & 1 & 168.2 & 174.9 & 176.0 \\
\hline 23 & 1 & 170.6 & 176.6 & 177.5 \\
\hline 24 & 2 & 172.8 & 178.1 & 178.9 \\
\hline 25 & 2 & 174.8 & 179.4 & 180.2 \\
\hline 26 & 2 & 176.6 & 180.6 & 181.3 \\
\hline 27 & 2 & 178.3 & 181.6 & 182.2 \\
\hline 28 & 2 & 179.9 & 182.6 & 183.1 \\
\hline 29 & 2 & 181.3 & 183.4 & 183.9 \\
\hline 30 & 2 & 182.6 & 184.2 & 184.6 \\
\hline 31 & 2 & 183.8 & 184.8 & 185.2 \\
\hline 32 & 2 & 184.9 & 185.4 & 185.7 \\
\hline 33 & 2 & 185.9 & 186.0 & 186.2 \\
\hline 34 & 2 & 186.8 & 186.4 & 186.6 \\
\hline 35 & 2 & 187.7 & 186.9 & 187.0 \\
\hline 36 & 3 & 188.4 & 187.2 & 187.3 \\
\hline
\end{tabular}

than that of female crabs, and this is evident after maturity has been reached. In the present study, the $14^{\text {th }}, 15^{\text {th }}$, and $16^{\text {th }}$ instars of the male attained a total average weight of $123.14 \mathrm{~g}, 188.92 \mathrm{~g}$ and $275.00 \mathrm{~g}$, respectively, whereas females recorded $106.50 \mathrm{~g}, 150.50 \mathrm{~g}$ and $210.33 \mathrm{~g}$ respectively. Accentuation of the larger 
increments in weight at moulting of male crabs may be due to the allometric growth of their chelae. Moult frequency in male crabs seems to be more closely related to total live weight than to carapace width. Female moult frequency was also related to carapace width and total live weight. Other workers also reported that the difference between the sexes is probably due to the greater size of the male chelae, which results in male crabs being heavier than females of the same carapace width (Hancock \& Edwards, 1967; Bennett, 1974). In the present study female crabs took more days to reach the $16^{\text {th }}$ instar than males, even though the growth in females is slightly faster till they attain $100 \mathrm{~mm}$ carapace width. To reach the $16^{\text {th }}$ instar stage from the first, males took an average of 272 days only but females attained the same stage after 332 days, even though their total carapace width and total weight were less. Bennet (1974), Mc Caughran \& Powell (1977), and Melville-Smith (1989) also reported similar findings in other species of crabs.

Mauchline (1976) concluded that the length of the intermoult period increased directly as the cube of the body length, or logarithmically as the body length, or in relation to the successive moultings. Present findings are also in conformity with Carroll (1982), who reported that unsexed juveniles have a constant ratio between chela height and carapace width up to approximately $65 \mathrm{~mm} \mathrm{CW}$. Beyond this size, discontinuous relative growth occurs as chela height to carapace width ratios of sexually mature males and females diverge from the juvenile proportions.

In crustaceans, lost appendages are replaced only by moulting. Smith (1990) has conducted studies to examine long-term effects of autotomy on the growth of the portunid crab, Callinectes sapidus Rathbun, 1896. He found that after loss of a single cheliped, the animal could regenerate almost $90 \%$ of its normal limb length in the first moult following autotomy, and nearly $100 \%$ by the second moult. In the present observations, too, Portunus pelagicus was able to regenerate a lost single chela or other limbs, to $90 \%$ of their normal size in the next moult, and this did not affect the moult increment or moult interval. However, in multiple limb loss both moult interval and moult increment were adversely affected. The effects of limb loss appear to be additive, such that the moult increment decreases proportionally as increasing numbers of limbs are lost (Bennett, 1973; Kuris \& Mager, 1975). Studies on the same species by Ary et al. (1987), showed that limb removal in early stages of anecdysis did not significantly affect the duration of the intermoult period compared to the intact controls.

The two most important environmental factors that affect moulting and growth in crustaceans, are temperature and the quality and quantity of food. Compared to these parameters, light and salinity have little effect on both moulting and intermoult period. In India, largely a tropical country, the growth of $P$. pelagicus is not influenced by the almost uniform ambient temperature, and the more so at Mandapam, where the temperature is always on the higher side and fluctuations are 
minimal throughout the year, such in contrast to temperate regions. Leffler (1972) reports that in Callinectus sapidus average growth rate increased with increase in temperature from $13^{\circ} \mathrm{C}$ to $34^{\circ} \mathrm{C}$. He also mentions that C. sapidus farms, where heated effluent water in the winter and cooler offshore water during summer are used, could grow blue crabs from first instar to market size in 7 to 8 months rather than the normal 10-11 months. Salinity variations were only marginal: hence, it is assumed that salinity is not a major factor determining or controlling growth. In his comprehensive review, Hartnoll (1982) likewise concluded that many growth studies in several species of crustaceans found no significant changes in the intermoult period with reference to salinity.

\section{ACKNOWLEDGEMENTS}

The authors wish to express their sincere gratitude to the Director of the Central Marine Fisheries Research Institute, Cochin, for providing facilities and to the Head of the Crustacean Fisheries Division for support and encouragements. JJ is grateful to Shri. P.E. Sampson Manickam, Principal Scientist (Retd.), Crustacean Fisheries Division, CMFRI, Cochin, for his critical comments. JJ profusely thanks Dr. Sunil Kumar Mohammed, Senior scientist, Molluscan Fisheries Division, CMFRI, for help rendered during data analysis.

\section{REFERENCES}

Ameer Hamsa, K. M. S., 1982. Observations on moulting of crab Portunus pelagicus Linnaeus, 1758 reared in the laboratory. Journ. mar. biol. Ass. India, 24: 69-71.

Ary, R. D., JR., C. K. Bartell \& M. A. Poirrier, 1987. The effects of chelotomy on molting in the blue crab, Callinectes sapidus Rathbun, 1896. Journ. Shellfish Res., 6: 103-108.

BennetT, D. B., 1973. The effect of limbloss and regeneration on growth of the edible crab, Cancer pagurus Linnaeus, 1758. Journ. exp. mar. Biol. Ecol., 13: 45-53.

_ _, 1974. Growth of the edible crab Cancer pagurus Linnaeus, 1758, off south-west England. Journ. mar. biol. Ass. U.K., 54: 803-823.

Butler, T. H., 1961. Growth and age determination of the Pacific edible crab Cancer magister Dana, 1852. Journ. Fish. Res. Bd Canada, 18: 873-891.

CArroll, J. C., 1982. Seasonal abundance, size composition and growth of rock crab, Cancer antennarius Stimpson, 1856, off central California. Journ. Crust. Biol., 2 (7): 549-561.

FABENS, A. J., 1965. Properties and fitting of the Von Bertalanffy growth curve. Growth, 29: 265289.

Gulland, J. A. \& S. J. Holt, 1959. Estimation of growth parameters for data at unequal time intervals. Journ. Cons. CIEM, 25 (1): 47-49.

HANCOCK, D. A. \& E. EDWARDS, 1967. Estimation of annual growth in the edible crab (Cancer pagurus Linnaeus, 1758). Journ. Cons. Perm. int. Explor. Mer, 31: 22-44.

Hartnoll, R. G., 1982. Growth. In: L. G. Abele, (ed.), The biology of Crustacea, 2, Embryology, morphology and genetics: 111-185. (Academic Press, New York). 
Hiatt, R. W., 1948. The biology of the lined shore crab, Pachygrapsus crassipes Randall, 1839. Pacific Sci., 2: 134-215.

JosileEN, J., 2001. On the fishery, biology and hatchery technology of the portunid crab Portunus pelagicus (Linnaeus, 1758): 1-137. (Ph.D thesis, Cochin University of Science and Technology, Cochin).

Josileen, J. \& N. G. Menon, 2004. Larval stages of the blue swimmer crab, Portunus pelagicus (Linnaeus, 1758) (Decapoda, Brachyura). Crustaceana, 77 (7): 785-803.

KuRIS, A. M. \& M. MAGER, 1975. Effect of limb regeneration on size increase at molt of the shore crabs Hemigrapsus oregonensis Dana, 1851, and Pachygrapsus crassipes Randall, 1839. Journ. exp. Zool., 193: 105-112.

LEFFLER, C. W., 1972. Some effects of temperature on the growth and metabolic rate of juvenile blue crabs, Callinectes sapidus, in the laboratory. Mar. Biol., Berlin, 14: 104-111.

Maheswarudu, G., E. V. Radhakrishnan, N. N. Pillai, S. Mohan, M. R. Arputharaj, A. Ramakrishnan \& A. Viramoni, 1996. Repetitive spawning of Penaeus indicus without eye stalk ablation, hatching rate and growth up to juveniles. Fishing Chimes, 16 (3): 21-23.

Mackay, D. C. G. \& F. W. Weymouth, 1935. The growth of the Pacific edible crab, Cancer magister Dana. Journ. biol. Bd Canada., 1: 191-212.

Mauchline, J., 1976. The Hiatt growth diagram for Crustacea. Mar. Biol., Berlin, 35: 79-84.

McCaughran, D. A. \& G. C. Powell, 1977. Growth model for Alaska king crab Paralithodes camtschatica (Tilesius, 1815). Journ. Fish. Res. Bd Canada, 34: 989-995.

Melville-Smith, R., 1989. A growth model for the deep sea red crab (Geryon maritae (Manning \& Holthuis, 1981)) off South-West Africa/Namibia (Decapoda, Brachyura). Crustaceana, 56: 279-292.

Menon, M. K., 1952. A note on the bionomics and fishery of the swimming crab Neptunus sanguinolentus (Herbst,1783) on the Malabar Coast. Journ. zool. Soc. India, 4: 177-184.

MunRo, J. L., 1982. Estimation of the parameters of the Von Bertalanffy growth equation from recapture data at variable time intervals. Journ. Cons. CIEM, 40: 199-200.

PRASAD, R. R. \& P. R. S. TAMPI, 1953. A contribution to the biology of the blue swimming crab, Neptunus pelagicus (Linnaeus, 1758) with a note on the zoeae of Thalamita crenata Latreille. Journ. Bombay nat. Hist. Soc., 51: 674-689.

SATHER, B. T., 1966. Observations on the moult cycle and growth of the crab Podophthalmus vigil (Fabricius, 1798) (Decapoda, Portunidae). Crustaceana, 11: 185-197.

SKInNer, D. M., 1985. Molting and regeneration. In: D. E. Bliss \& L. H. Mantel (eds.), The biology of Crustacea, 9, Integument, pigment and hormonal processes: 44-128. (Academic Press, New York).

SMith, L. D., 1990. Patterns of limb loss in the blue crab, Callinectes sapidus Rathbun, and the effects of autotomy on growth. Bull. mar. Sci., 46: 23-35.

Williamson, H. C., 1900. Contributions to the life history of the edible crab (Cancer pagurus Linn.). Rep. Fish. Bd Scotland, 18: 77-143.

First received 8 April 2004.

Final version accepted 1 October 2004. 